\title{
Analisis Dampak Pembelajaran Daring Terhadap Hasil Belajar Geografi Siswa SMAN 2 Labuapi pada Masa Pandemi Covid-19
}

\author{
Zaedun \\ SMA Negeri 2 Labuapi, Kota Mataram - Provinsi NTB \\ *Corresponding Author. Email: atazaedun@gmail.com
}

\begin{abstract}
This study aims to analyze the impact of online learning on student learning outcomes in the Geography subject, the subject matter of Population Data Processing and Analysis in class XI IPS SMAN 2 Labuapi during the Covid-19 pandemic. This research method uses a descriptive method with a qualitative approach. The subjects of this study were students of class XI IPS 1, totaling 30 people. Data collection techniques using observation, documentation, and interviews. While the data analysis technique using interactive analysis includes data reduction, data presentation, and drawing conclusions. The results showed that online learning had an impact on student learning outcomes on the subject matter. Population Data Sources learning outcomes of 30 students showed $93 \%$ of students achieved completeness and only $7 \%$ had not. The average value of student learning achievement in this subject matter reached 81.83 .
\end{abstract}

Abstrak: Penelitian ini bertujuan untuk menganalisis dampak pembelajaran daring terhadap hasil belajar siswa pada mata pelajaran Geografi materi pokok Pengolahan dan Analisis Data Kependudukan di kelas XI IPS SMAN 2 Labuapi pada masa pandemic Covid-19. Metode penelitian ini menggunakan metode deskriptif dengan pendekatan kualitatif. Subyek penelitian ini adalah siswa kelas XI IPS 1 yang berjumlah 30 orang. Teknik pengumpulan datanya menggunakan observasi, dokumentasi, dan wawancara. Sedangkan teknik analisis datanya menggunakan analisis interaktif meliputi reduksi data, peyajian data, dan penarikan kesimpulan. Hasil penelitian menunjukan bahwa pembelajaran daring berdampak pada hasil belajar siswa pada materi pokok Sumber Data Kependudukan capaian hasil belajar dari 30 siswa menunjukkan 93\% siswa mencapai ketuntasan dan hanya $7 \%$ yang belum tuntas. Rata-rata nilai capain belajar siswa pada materi pokok ini mencapai 81,83 .

\section{Article History}

Received: 26-09-2021

Revised: 01-11-2021

Accepted: 19-11-2021

Published: 07-01-2022

\section{Key Words:}

Online Learning, Learning Outcomes, Geography, Covid-19.

\section{Sejarah Artikel}

Diterima: 26-09-2021

Direvisi: 01-11-2021

Disetujui: 19-11-2021

Diterbitkan: 07-01-2022

\section{Kata Kunci:}

Pembelajaran Daring, Hasil Belajar, Geografi, Covid-19.

How to Cite: Zaedun, Z. (2022). Analisis Dampak Pembelajaran Daring Terhadap Hasil Belajar Geografi Siswa SMAN 2 Labuapi pada Masa Pandemi Covid-19. Jurnal Paedagogy, 9(1), $124-132$. doi:https://doi.org/10.33394/jp.v9i1.4326

do] https://doi.org/10.33394/jp.v9i1.4326

This is an open-access article under the CC-BY-SA License.

\section{Pendahuluan}

Pandemi Covid-19 menimbulkan permasalahan diberbagai sektor kehidupan salah satunya adalah pendidikan. hampir dua tahun lamanya pembelajaran daring dan pembelajaran tatap muka terbatas dilaksanakan. Diselingi juga dengan pembelajaran luar jaringan (luring) yang sudah ditentukan jadwalnya, agar pembatasan sosial tetap terlaksana dengan baik (Asmuni, 2020). Sejak diterbitkannya Surat Edaran No. 4 Tahun 2020 dari Kementerian Pendidikan dan Kebudayaan (Kemendikbud), tentang pelaksanaan kebijakan pendidikan dalam masa darurat penyebaran Corona Virus Disease (Covid-19), proses Belajar dari Rumah (BDR) dilaksanakan dengan ketentuan: (a) BDR melalui pembelajaran daring/ jarak jauh dilaksanakan untuk memberikan pengalaman belajar yang bermakna bagi siswa, tanpa terbebani tuntutan menuntaskan seluruh capaian kurikulum untuk kenaikan kelas maupun kelulusan; (b) BDR dapat difokuskan pada pendidikan kecakapan hidup antara lain 
mengenai pandemi Covid-19; (c) aktivitas dan tugas pembelajaran BDR dapat bervariasi antarsiswa, sesuai minat dan kondisi masing-masing, termasuk mempertimbangkan kesenjangan akses atau fasilitas belajar di rumah; (d) bukti atau produk aktivitas BDR diberi umpan balik yang bersifat kualitatif dan berguna dari guru, tanpa diharuskan memberi skor atau nilai kuantitatif (Mendikbud, 2020; Mas'udi, 2020; Nurhayati, 2020).

Pendidikan Jarak Jauh (PJJ) sebetulnya telah diatur dalam Undang-Undang (UU) Sisdiknas tahun 2003 bagian ke-10 Pasal 31, yang isinya: (1) PJJ diselenggarakan pada semua jalur, jenjang, dan jenis pendidikan. (2) PJJ dapat berfungsi memberikan layanan pendidikan kepada kelompok masyarakat yang tidak dapat mengikuti pendidikan secara tatap muka atau reguler. (3) PJJ diselenggarakan dalam berbagai bentuk, modus dan cakupan yang didukung oleh sarana dan layanan belajar serta sistem penilaian yang menjamin mutu lulusan sesuai dengan standar nasional pendidikan. (4) Ketentuan mengenai peyelenggaraan pendidikan jarak jauh sebagaimana yang dimaksud dalam ayat (1), ayat (2) dan ayat (3) diatur lebih lanjut dengan Peraturan Pemerintah (Undang-Undang No. 20 Tahun 2003) (Ahmad, 2020).

PJJ di masa pandemi seperti saat ini mengharuskan siswa belajar dari rumah. Salah satu strategi dan bentuk mitigasi meminimalisasir penyebaran Covid-19 adalah pembelajaran daring. Kemajuan teknologi telah memungkinkan pemanfaatan jaringan internet untuk BDR (akbar et al., 2021). Dengan jaringan internet para pendidik dapat melakukan proses belajar mengajar dengan membagikan materi melalui platform tertentu, bahkan bisa bertatap muka langsung dengan siswa melalui sambungan video. Sehingga proses komunikasi dua arah pada proseses belajar mengajar dimungkinkan; antara guru dengan siswa, siswa dengan siswa, dan guru dengan guru. Diharapkan dengan proses belajar daring siswa dapat memiliki prestasi belajar yang baik, karena media belajar yang digunakan dalam mempelajari materi semakin beragam. Guru memberikan materi dengan merujuk dari berbagai macam sumber, tidak hanya yang telah disediakan secara khusus oleh pemerintah, namun juga dari berbagai sumber dalam website, baik itu artikel, video youtube (Amlin, 2021; Emilia et al., 2021).

Hasil belajar merupakan kemampuan yang diperoleh anak setelah kegiatan belajar. Seseorang dapat dikatakan telah berhasil dalam belajar jika ia mampu menunjukkan adanya perubahan dalam dirinya. Perubahan-perubahan tersebut diantaranya dari segi kemampuan berpikir, keterampilan, atau sikap terhadap suatu objek (M. Abdurrohman, 2003; Suarni et al., 2021). Prestasi yang diharapkan melalui proses pembelajaran daring adalah tercapainya ketuntasan belajar siswa yang mengacu pada Kompetensi Ketuntasan Minimal (KKM), dicirikan dengan siswa yang memperoleh nilai sesuai dengan KKM yang ditentukan bahkan melampaui KKM tersebut. Khusus untuk ketuntasan belajar mata pelajaran geografi di kelas XI IPS SMAN 2 Labuapi adalah 75\%. Jadi, siswa dianggap sudah mencapai KKM apabila bisa mendapatkan nilai minimal 75. Upaya mendukung ketercapaian KKM, pembelajaran daring mata pelajaran geografi menggunakan platform Google Classroom (GC), materi dan penugasan dikirimkan oleh guru melalui GC, baik berupa file materi, video pembelajaran dan Lembar Kerja Peserta Didik (LKPD).

Evaluasi pembelajaran daring yang telah dilaksakan selama pandemi secara umum berjalan dengan baik. Namun, terkait dengan ketercapaian KKM pada mata pelajaran geografi kelas XI IPS SMAN 2 Labuapi menunjukkan perbedaan yang signifikan. Khusus pada indikator Materi Pengolahan dan Analisis Data Kependudukan, ketercapaian KKM siswa sangat rendah. Sedangkan pada indikator materi yang lainnya, ketercapaian KKM siswa menunjukkan hasil yang baik. 
Kondisi tersebut tentunya suatu masalah yang harus diteliti lebih lanjut, guna memahami secara komperhensif apakah sepesifik merupakan dampak dari strategi pembelajaran daring atau ada faktor eksternal lainnya. Oleh karena itu, penelitian ini bertujuan menganalisis dampak pembelajaran daring terhadap hasil belajar siswa pada mata pelajaran geografi kelas XI IPS SMAN 2 Labuapi tahun pelajaran 2021/2022. Mengacu pada hasil temuan penelitian ini yang dapat menjadi evaluasi pembelajaran, direkomendasikan strategi untuk peningkatan kualitas dan produktivitas pembelajaran daring selama pandemi.

\section{Metode Penelitian}

Metode yang digunakan dalam penelitian ini adalah metode deskriptif dengan pendekatan kualitatif. Metode kualitatif deskriptif digunakan dalam penelitian ini untuk menemukan dan mendeskripsikan informasi dan data yang dapat menjelaskan fenomena sosial (Creswell, 2015). Subyek dalam penelitian ini adalah capaian nilai KKM kelas XI IPS 1 yang terdiri dari 30 siswa dan 5 wali siswa. Data diproleh dengan teknik observasi, dokumentasi, dan wawancara. Data primer bersumber dari hasil evaluasi prestasi siswa pada materi pokok Pengolahan dan Analisis Data Kependudukan sebelum penerapan pembelajaran daring (sebelum pandemi) dan setelah penerapan pembelajaran daring (saat pandemi). Wawancara dengan wali siswa juga menjadi data primer.

Instrumen wawancara dikirimkan secara daring kepada siswa yang menjadi sampel, kemudian diteruskan ke wali masing-masing. Hasil dari wawancara tersebut kemudian direkam siswa dan dikirimkan kembali secara daring oleh siswa ke peneliti. Hal ini dilakukan untuk mematuhi pembatasan sosial dari pemerintah, guna mematuhi protokol kesehatan. Wawancara dengan wali murid bertujuan untuk memperoleh informasi dari respon penerapan pembelajaran daring yang diberlakukan. Analisis data penelitian ini dilakukan dengan reduksi data untuk menemukan hal-hal yang pokok, kemudian disajikan, dan dilakukan penarikan beberapa kesimpulan.

\section{Hasil Penelitian dan Pembahasan}

SMAN 2 Labuapi sebagai sekolah umum yang memiliki lokasi di Kabupaten Lombok barat yang berbatasan dengan kota Mataram. Walaupun memiliki lokasi pinggiran kota, gedung sekolah, sarana prasarana, serta kualifikasi guru-guru yang mengajar sudah sangat memadai. Pelaksanaan pembelajaran daring di SMAN 2 Labuapi selama ini sudah sejalan dengan prosedur standar pendidikan yang ditetapkan. Dibuktikkan dengan RPP daring yang dibuat oleh guru, dan didistribusikan pada siswa, serta menjadi pegangan bagi orang tua siswa. Mekanisme itu merupakan formulasi dari guru agar produktivitas pembelajaran daring berdampak pada pengetahuan dan sikap. Pada dasarnya dalam setiap situasi. proses pembelajaran membutuhkan peran serta aktif tidak hanya siswa dan guru, tapi juga orang tua siswa. Terlebih pada masa pembelajaran daring, porsi keterlibatan aktif orang tua sangat dibutuhkan dan perlu ditingkatkan. Selain itu, penyelarasan pembelajaran daring di SMAN 2 Labuapi dengan prosedur yang ada dapat terlaksana dengan baik berkat koordinasi yang solid antar pemangku kepentingan internal sekolah. Kepala sekolah dalam hal ini telah melakukan sosialisasi pelaksanaan pembelajaran secara maksimal, melibatkan segenap dewan guru dalam mengupayakan pemanfaatan media pembelajaran untuk menunjang pemahaman siswa dalam pelaksanaan pembelajaran daring.

Pelaksanaan pembelajaran daring di SMAN 2 Labuapi berpedoman pada surat edaran Dinas Pendidikan dan Kebudayaan Provinsi NTB dan langkah-langkah pembelajaran yang disepakati oleh KCD. Dalam surat edaran yang diberikan oleh dinas dijelaskan bahwa 
sebelum tahun ajaran baru 2020/2021 sebagai masa transisi dimulai, setiap satuan pendidikan melakukan beberapa persiapan seperti: (1) Menyiapkan perlengkapan protokol kesehatan pelaksanaan PJJ tersedia di setiap satuan pendidikan (sanitasi air tempat cuci tangan, sabun, hand sanitizer, masker, thermogun, disinfektan, APD, dll.); (2) Menyiapkan perangkat pembelajaran (silabus, RPP daring, instrumen penilaian, media pembelajaran daring, daftar nilai, presensi, modul, buku ajar, dll.); (3) Satuan pendidikan mensosialisasikan persiapan dan rancangan PJJ/BDR masa transisi tahun ajaran 2020/ 2021 kepada orang tua peserta didik secara daring/luring dengan memperhatikan protokol kesehatan. Bahan sosialisasi diantaranya mengenai: (a) Maksud, tujuan, dan alasan pembelajaran daring; (b) Inventarisasi ketersediaan sarana pembelajaran daring yang dimiliki peserta didik; (c) Teknis pelaksanaan BDR, jadwal pembelajaran PJJ; (d) Media pembelajaran yang digunakan dalam PJJ; (e) Guru yang akan mengajar BDR; (f) Bahan, materi, sumber belajar yang akan digunakan (buku, modul, LKPD, dll.) dalam BDRdaring; (g) Pembuatan grup media komunikasi (WA, FB, GC, dll.); (h) Penyerahan sumber bahan ajar, alat pembelajaran, instrumen evaluasi yang akan digunakan dalam PJJ/ BDR.

Khusus bagi peserta didik baru (siswa kelas 1), satuan pendidikan dapat menghadirkan orang tua peserta didik bersama peserta didik terlebih dahulu secara bertatap dengan protokol kesehatan untuk melakukan koordinasi dan sosialisasi pembelajaran BDR dan pengenalan guru/sekolah dengan durasi maksimal 1,5 jam pertemuan. Kepala sekolah memastikan persiapan telah dilakukan di setiap satuan pendidikan masing-masing dengan validasi oleh pengawas sekolah. Untuk itu dalam melaksanakan pembelajaran daring di SMAN 2 Labuapi ini memakai standar pendidikan yang ada dan berpedoman pada dinas pendidikan sesuai prosedurnya.

Pembelajaran daring, akronim dari "dalam jaringan", adalah proses belajar mengajar yang memanfaatkan internet sebagai media utama. Penyelenggaraannya sejak awal tahun 2020 merupakan strategi model pembelajaran sekaligus mitigasi pandemi Covid-19. Praktek pelaksanaan pembelajaran daring bervariasi, menyesuaikan dengan karakteristik masingmasing sekolah namun tetap selaras dengan standar praturan yang ada. Bagi guru yang mengajar, dalam melaksanakan daring ini tentunya juga berpedoman pada standar yang telah ditetapkan oleh sekolah, untuk itu kaitannya dengan persiapan perangkat pembelajaran setiap guru mata pelajaran membuat sesuai pedoman yang ada, dalam perencanaan pembuatan RPP disusun dengan RPP daring, yang sedikit berbeda antara RPP sebelumnya. RPP daring lebih singkat perbedaan terletak di kegiatan pembelajarannya. RPP sebelumnya lebih prosedural karena kegiatan bisa berlangsung tatap muka. untuk RPP daring, kegiatan pembelajarannya hanya pembukaan salam dan doa bersama dirumah masing-masing, dan dilanjutkan penugasan atau video materi yang dishare, kegiatan penutup pun hanya diisi dengan mengshare nilai dan tanya jawab. Untuk alokasi waktu lebih panjang dipembelajaran daring, karena kegiatan belajar di rumah orang tuapun terkadang ada yang bekerja sampai malam sehingga pendampingan anak hanya dilakukan ketika orang tua sudah pulang dari tempat kerjanya. Bahkan kebanyakan siswa tidak di dampingi sama sekali oleh wali nya. Untuk presensi tiap harinya yang di hitung adalah list pengumpulan tugas sebagai patokan bahwa siswa tersebut mengikuti pembelajaran daring di setiap harinya.

Adapun mengenai pelaksanaan pembelajaran daring dilakukan dengan cara memberikan materi mengenai Pengolahan dan Analisis Data Kependudukan melalui GC, baik berupa materi portable document format (pdf), video dan link pembelajaran yang berkaitan dengan materi yang diberikan. Pemberian materi maupun penugasan dilakukan sesuai jadwal yang telah di berikan oleh Wakil Kepala Sekolah bagian Kurikulum. Untuk 
geografi, materi diberikan seminggu sekali, kemudian baru diberikan tugas dalam bentuk LKPD, kuis dan lainnya.

Setiap perubahan cenderung menghadirkan sesuatu yang baru dan membutuhkan penyesuaian. Demikian halnya yang terjadi dengan penerapan pembelajaran daring. Aktivitas pembelajaran dalam jaringan merupakan sesuatu hal yang baru bagi guru, siswa, dan orang tua. Sistem pembelajaran yang merupakan alternatif di tengah pandemi yang sedang melanda, tentu menghadirkan solusi dan banyak kemudahan. Namun, juga menghadirkan kendalakendala yang membutuhkan penyesuaian

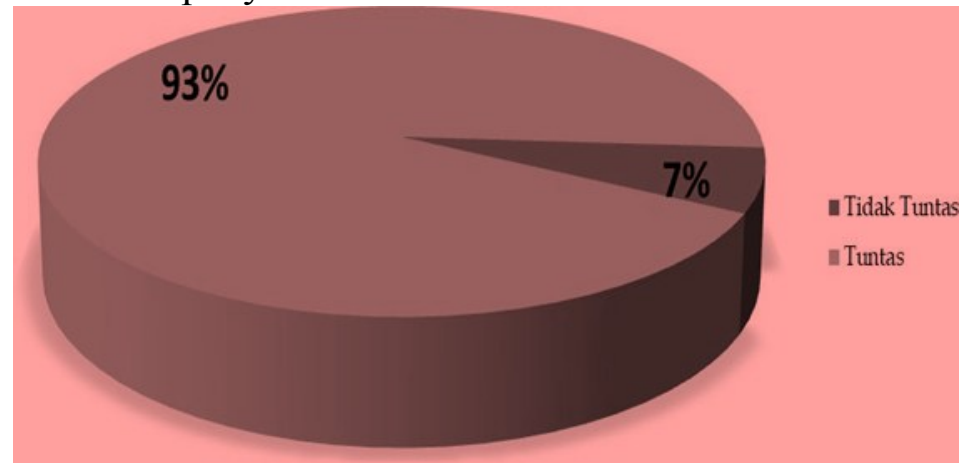

\section{Gambar 1. Capaian Hasil Belajar IX IPS 1 Materi Pokok Sumber Data Kependudukan}

Mengacu pada hasil evaluasi capaian belajar pada mata pelajaran geografi di kelas XI IPS SMAN 2 Labuapi dengan sampel dari kelas XI IPS 1 menunjukkan perbedaan capaian hasil belajar yang sangat signifikan antar satu materi pokok dengan materi pokok yang lainnya. Dalam penelitian ini digunakan komparasi antara capaian hasil belajar pada materi pokok Sumber Data Kependudukan dengan capaian hasil belajar pada materi Pengolahan dan Analisis Kependudukan selama pembelajaran daring. KKM dalam mata pelajaran geografi adalah 75. Pada materi pokok Sumber Data Kependudukan capaian hasil belajar dari 30 siswa menunjukkan 93\% siswa mencapai ketuntasan dan hanya $7 \%$ yang belum tuntas (Gambar 1). Rata-rata nilai capain belajar siswa pada materi pokok ini mencapai 81,83.

Metode pembelajaran dan KKM yang sama juga diterapkan pada materi pokok Pengolahan dan Analisis Kependudukan. Hasil evaluasi menunjukkan adanya penurunan yang sangat signifikan pada hasil capaian belajar siswa pada materi ini dibanding dengan materi pokok yang lain. Penurunan mencapai 40\%. Pada materi pokok ini 53\% siswa mencapai ketuntasan dan 47. Penurunan hasil capaian belajar siswa pada materi pokok Pengolahan dan Analisis Kependudukan yang sangat signifikan jika dibanding dengan capaian pada materi pokok yang lain menunjukkan adanya indikasi kendala dalam proses pembelajaran daring berkaitan dengan karakter dari masing-masing materi pokok. Jika meninjau Silabus dan RPP materi pokok Sumber Data Kependudukan, pada materi pokok tersebut merupakan materi hitungan dengan banyak rumus dan jumlah nilai yang dihitung cukup besar. Berlainan dengan materi pokok yang lainnya yang hanya merupakan pemahaman teori dan konsep, bersifat hafalan. Temuan ini mengasumsikan bahwa pembelajaran daring yang mengharuskan siswa belajar dari rumah karena pandemi Covid-19 menuntut inovasi dari guru untuk menerapkan strategi belajar yang berbeda-beda, menyesuaikan dengan karakteristik masing-masing materi pokok. Rosali (2020) melalui hasil analisis penelitiannya mengenai aktifitas pembelajaran daring pada masa pandemi Covid-19 pada jurusan pendidikan geografi di tingkat Universitas dengan temuan yang cendrung sama merekomendasikan model pembelajaran daring yang lebih variatif agar tetap menarik jika 
digunakan jangka panjang. Selain itu, dari hasil temuan penelitian ini, keterlibatan aktif orang tua siswa di rumah untuk melakukan pendampingan sangat dibutuhkan, agar hasil dari proses belajar berupa pengetahuan dan keterampilan mencakup ranah kognitif, afektif, dan psikomotorik tetap tercapai melalui metode pembelajaran daring.

Pembelajaran daring, BDR/PJJ, menuntut keterlibaran aktif yang kolaboratif antara guru dan orang tua siswa untuk memantau dan mendampingi siswa. Pada sistem pembelajaran konvensional, orang tua siswa relatif tidak merasa wajib melakukan pendampingan dalam proses belajar siswa/ anaknya. Orang tua fokus dengan tugas dan fungsi pokoknya; mengurus rumah tangga dan bekerja mencari nafkah. Pendidikan anak sepenuhnya adalah tugas guru di sekolah. Namun, BDR secara daring sangat membutuhkan kehadiran orang tua sebagai guru bagi anaknya, selayaknya guru di sekolah. Hasil temuan yang diproleh dari wawancara, rata-rata orang tua siswa memiliki kendala yang berbeda-beda terkait adanya pembelajaran daring. Seperti yang diutarakan oleh bapak JE, ia tidak memiiki waktu luang untuk mendampingi anaknya karena harus mencari nafkah:

"Saya tidak pernah mendampingi anak saya belajar, karena saya juga harus mencari uang untuk hidup sehari-hari. Saya hanya percayakan kepada anak saya untuk belajar mandiri. Namun, saya lebih suka melihat anak saya sekolah seperti hari biasanya. Saya kasihan melihat anak saya, dia sering mengeluh karena tidak tahu kalau ada tugas, karena tidak memiliki HP yang memadai. Dia sering tidak mengumpulkan tugas-tugasnya (Wawancara dengan bapak JE, wali murid dari HJ).

Kendala lain yang dihadapai orang tua saat mendampingi anaknya pada masa belajar daring adalah kurang sabar. Seperti yang ditemukan pada kasus bapak SD. Karakternya yang mudah marah menyebabkan ia sering tidak sabaran saat mendampingi RS anaknya belajar daring:

"Saya kan sibuk bekerja, jadi untuk memantau dan mendampingi anak saya kurang maksimal. Terlebih saya itu tipe orang yang keras, jika anak saya diajarin susah ya saya serahkan saja sama anak saya, tak suruh ngerjain sebisanya. Saya juga dirumah istilahnya kurang waktunya jadi untuk mendampingi pun terbatas" (Wawancara dengan bapak $S D$, wali murid $R S$ ).

Ketidakmampuan orang tua memahami apa yang dipelajari anaknya semakin melengkapi kendala yang dihadapi saat pembelajaran daring. Orang tua yang diharapkan berperan aktif mendampingi anaknya saat pembelajaran daring di masa Covid-19 ternyata dihadapkan pada kondisi semacam itu. Seperti yang diutarakan oleh bapak MD:

"Dalam pembelajaran daring saya hanya sekedar mendampingi anak saya dengan duduk di sampingnya saja sebentar, karena saya hanya ingin memastikan dia benar-benar belajar atau tidak. Saya tidak bisa membimbingnya untuk belajar karena materi-materi SMA sangat sulit dan saya tidak bisa memahaminya. Setiap dia mengatakan sedang belajar, saya berusaha hanya duduk menemani saja. Anak saya bahkan terkadang tidak suka saya temani, jadi saya awasi saja dari jauh. Saya merasa pembelajaran daring ini tidak begitu efektif, karena sering saya lihat anak saya kebingungan dalam mengerjakan tugas-tugasnya, karena dia tidak faham dengan materi yang sudah dikirim oleh gurunya lewat google (Wawancara dengan bapak MD, wali murid dari PH).

Jika secara konseptual pembelajaran adalah proses intraksi antara pendidik dan peserta didik dalam suatu lingkungan belajar untuk mencapai tujuan belajar. Maka, penerapan pembelajaran daring saat pandemi, menuntut peran aktif orang tua siswa layaknya peran guru di sekolah. Namun pada kenyataannya harapan tersebut dihadapkan pada kondisi tidak bisa maksimalnya orang tua siswa untuk menjalankan tugas dan fungsi tersebut. Sehingga pada 
materi pokok yang memuat konten rumus dan hitungan, seperti materi pokok Pengolahan dan Analisis Kependudukan, 47\% dari 30 siswa tidak mencapai ketuntasan belajar. Bila menyimak hasil analisis Ratiwi \& S., (2020) mengenai peran orang tua dalam pendampingan pembelajaran daring yang bermanfaat terhadap perkembangan kognitif anak, dibutuhkan pengawasan dengan keterbukaan komunikasi untuk menciptakan suasana yang hangat dan nyaman dalam mendorong, memotivasi, dan mengarahkan kemauan anak saat belajar.

Bersumber dari wawancara yang dilakukan dengan wali murid, ditemukan juga komorbid (penyakit bawaan) berupa beban pembelian kuota internet di tengah menurunnya penghasilan para orang tua. Seperti yang dikeluhkan ibu AH wali murid RN; "Belajar di masa sekarang ini, sangat merepotkan saya, karena anak-anak saya selalu minta untuk membelikan pulsa. Sedangkan penghasilan saya di masa pandemi ini juga menurun. Kondisi tersebut juga memunculkan harapan dari wali murid/ orang tua siswa agar anaknya lebih baik belajar seperti sedia kala, belajar langsung di sekolah. Bapak AM wali murid ZF mengatakan; "Saya lebih senang melihat anak saya belajar ke sekolah seperti biasanya daripada di rumah, karena biaya ke sekolah lebih murah dari pada biaya pulsa internet yang harus saya belikan. Lemahnya kondisi ekonomi karena pandemi dan pemanfaatan kuota belajar yang masih belum tepat guna, menjadi masalah yang tidak kalah krusialnya pada masa pembelajaran daring. Kondisi semacam ini oleh Briliannur, (2020) yang juga melakukan analisis efektivitas pembelajaran daring di masa pandemi Covid-19 menjadi penyebab kurang efektifnya pembelajaran daring karena faktor minimnya sarana dan prasarana serta literasi teknologi. Penelitian di tingkat universitas, yang dilakukan Rosali, (2020), selain kendala kuota internet, jaringan internet yang tidak setabil dilokasi masingmasing siswa juga menjadi kendala saat pembelajaran daring.

\section{Kesimpulan}

Secara umum pelaksanaan pembelajaran Daring di SMAN 2 Labuapi telah berjalan dengan baik, sesuai dengan standar pendidikan yang diberlakukan. Dalam pembelajaran Daring selalu dipersiapkan perangkat pembelajaran seperti RPP, silabus, instrumen penilaian, dan media pembelajaran lainnya. Namun, karakteristik dari masing-masing materi pokok pelajaran ternyata berpengaruh pada hasil pencapaian belajar siswa. Pada materi pokok Pengolahan dan Analisis Kependudukan yang banyak memuat rumus dan hitungan, siswa mengalami kendala belajar secara daring. Hal ini ditunjukkan dengan rendahnya capaian hasil belajar siswa, banyak siswa yang tidak tuntas mencapai batas minimal KKM 75. Dari 30 siswa, $47 \%$ tidak tuntas. Sedangkan jika merujuk pada materi pokok yang lain yang hanya memuat teori dan konsep, seperti pada materi pokok Sumber Data Kependudukan, hanya 7\% siswa yang tidak tuntas dan 93\% tuntas. Ketimpangan yang signifikan (sebesar 40\%) dari hasil komparasi capaian belajar siswa di dua materi tersebut menunjukkan dampak pembelajaran daring pada mata pelajaran geografi di kelas XI IPS SMAN 2 Labuapi.

Setelah dilakukan pengamatan, kajian dan analisis, pembelajaran daring yang menuntut keterlibatan aktif orang tua siswa di rumah untuk mendampingi siswa saat belajar ternyata menghadapi kendala, seperti minimnya waktu luang karena orang tua sibuk bekerja, adanya kecenderungan orang tua yang tidak sabar dalam melakukan pendampingan, orang tua merasa kewalahan melakukan pendampingan karena tidak memahami apa yang dipelajari anaknya, serta biaya pengadaan kuota internet yang dirasa membebani di tengah menurunya pendapatan ekonomi orang tua karena pandemi. 


\section{Saran}

Adapun saran yang disampaikan berdasarkan hasil penelitian ini yakni komplikasi masalah yang dihadapi dalam pembelajaran daring membutuhkan strategi yang jitu dan bersifat afirmatif. Untuk itu perlu diadakan evaluasi pelaksanaan pembelajaran daring setiap akhir bulan antara guru, siswa dan orang tua. Sehingga ketika metode atau sistem daring dirasa kurang cocok atau menghadapi banyak permasalahan, orang tua dan siswa dapat memberi masukan, kemudian guru atau pihak sekolah segera mengambil langkah perbaikan. Pada dasarnya kolaborasi yang koopratif antaraguru, siswa, dan orang tua siswa sangat dibutuhkan dalam proses pembelajaran, terlebih dalam pembelajaran daring.

\section{Daftar Pustaka}

Ahmad, A. (2020). Peningkatan Kompetensi Pedagogik Guru dalam Pembelajaran Jarak Jauh Melalui Pendampingan Sistem Daring, Luring, atau Kombinasi pada Masa New Normal Covid-19. Jurnal Paedagogy, 7(4), 258-264. doi:https://doi.org/10.33394/jp.v7i4.2803

Akbar, K., Hamdi, H., Kamarudin, L., \& Fahruddin, F. (2021). Manajemen POAC pada Masa Pandemi Covid-19 (Studi Kasus BDR di SMP Negeri 2 Praya Barat Daya). Jurnal Kependidikan: Jurnal Hasil Penelitian dan Kajian Kepustakaan di Bidang Pendidikan, Pengajaran dan Pembelajaran, 7(1), 167-175. doi:https://doi.org/10.33394/jk.v7i1.2959

Amlin, A. (2021). Peningkatan Hasil Belajar Matematika dengan Media Google Classroom dan WhatsApp Sebagai Media Pembelajaran Daring pada Masa Pandemi Covid-19 bagi Siswa Kelas XII Busana 2 SMK Negeri 3 Baubau. Jurnal Paedagogy, 8(3), 431-437. doi:https://doi.org/10.33394/jp.v8i3.3907

Asmuni, A. (2020). Problematika Pembelajaran Daring di Masa Pandemi Covid-19 dan Solusi Pemecahannya. Jurnal Paedagogy, 7(4), 281-288. doi:https://doi.org/10.33394/jp.v7i4.2941

Briliannur. (2020). Analisis Keefektifan Pembelajaran Online di Masa Pandemi Covid-19. Jurnal Pendidikan Guru Sekolah Dasar, 28-37.

Creswell, J. W. (2015). Penelitian Kualitatif \& Desain Riset. Yogyakarta: Pustaka Pelajar.

Emilia, J., Ismanto, B., \& Luhsasi, D. (2021). Evaluasi Implementasi Pembelajaran Daring pada Pembelajaran Akuntansi Perusahaan Dagang di Masa Pandemi Covid19. Jurnal Kependidikan: Jurnal Hasil Penelitian dan Kajian Kepustakaan di Bidang Pendidikan, Pengajaran dan Pembelajaran, 7(3), 663-671. doi:https://doi.org/10.33394/jk.v7i3.3849

M. Abdurrohman. (2003). Pendidikan bagi Anak Berkesulitan Belajar. Jakarta: Rineka Cipta. Mas'udi, W., \& (Ed.), P. S. W. (2020). Tata Kelola Penanganan COVID-19 di Indonesia: Kajian Awal. Yogyakarta: UGM Press.

Mendikbud. (2020). Surat Edaran Nomor 4 Tahun 2020 tentang Pelaksanaan Kebijakan Pendidikan dalam Masa Darurat Penyebaran Covid-19. Retrieved from http://pgdikmen.kemdikbud.go.id/read-news/surat- edaran-mendikbud-nomor4-tahun-2020

Nurhayati, E. (2020). Meningkatkan Keaktifan Siswa Dalam Pembelajaran Daring Melalui Media Game Edukasi Quiziz pada Masa Pencegahan Penyebaran Covid-19. Jurnal Paedagogy, 7(3), 145-150. doi:https://doi.org/10.33394/jp.v7i3.2645 
Ratiwi, R. D., \& S., W. (2020). Peran Orang Tua dalam Pendampingan Pembelajaran Daring Terhadap Perkembangan Kognitif. Seminar Nasional Pascasarjana UNNES, 304309.

Rosali, R. S. (2020). Aktifitas Pembelajaran Daring pada Masa Pandemi Covid-19 di Jurusan Pendidikan Geografi Universitas Siliwangi Tasikmalaya. Geography Science Education Journal (GEOSEE), 1(1), 21-30.

Suarni, G., Rizka, M., \& Zinnurain, Z. (2021). Analisis Pengaruh Penerapan Model Pembelajaran Sains Teknologi Masyarakat Terhadap Hasil Belajar Siswa. Jurnal Paedagogy, 8(1), 31-38. doi:https://doi.org/10.33394/jp.v8i1.3226

Undang-Undang No. 20 Tahun 2003 Tentang Sistem Pendidikan Nasional. 